\title{
Strength of cast-in-place slabs for rectangular cross-section columns punching
}

\author{
Andrey Istomin, and Maksim Kudryavtsev* \\ Moscow State University of Civil Engineering, Yaroslavskoe shosse, 26, Moscow, 129337, Russia
}

\begin{abstract}
Flat slabs in contemporary buildings are most commonly supported by rectangular cross-section columns. Research of slabs supported by rectangular cross-section columns for punching is rather narrow. The purpose of this work was the experimental research of slabs punching by rectangular cross-section columns and adjustment of their design method. Reinforced concrete slabs $6 \mathrm{~cm}$ in thickness without transverse reinforcement were used as testing specimens. During tests load on the slab was transferred using stamps. Side ratios for stamps varied from 1 to 5 in experiments. Strength and strain properties of concrete were determined before slabs testing for punching. Ultimate loads, that resulted in slab punching, were acquired from test results. Formulae for punching load are suggested for rectangular cross-section columns punching based on obtained results. Generalized analysis of experimental research results shows that slab strength for punching is also influenced by short side of rectangular cross-section to slab thickness ratio.
\end{abstract}

\section{Introduction}

Cast-in-place reinforced concrete buildings with beamless frame represent significant portion in nowadays construction. Flat floor slabs most commonly are supported by rectangular cross-section columns. Most experimental and theoretic studies associate with research of punching behavior of slabs supported by square cross-section columns [1-7]. Thereat research for slabs supported by rectangular cross-section columns is rather narrow [8-12]. Punching design for cast-in-place floor slabs according to SP 63.13330.2018 leads to overstatement of load bearing capacity by up to $40 \%$ in relation to experimental data [10, 13]. Analysis of numerical investigations for stress condition of cast-in-place slabs at punching loads showed that increase in rectangular cross-section columns sides ratio leads to significant non-uniformity in stress and strain distribution across column perimeter [1416]. Most propositions for accounting of non-uniformity in strain and stress distribution across the long side of rectangular columns cross-section come down to artificial reduction of design cross-section perimeter.

Research purpose - experimental research of slab strength for rectangular cross-section columns punching and adjustment of its design methods.

\footnotetext{
* Corresponding author: k.m.v.29.12.96@yandex.ru
} 


\section{Methods and materials}

Reinforced concrete slabs $100 \times 100 \mathrm{~cm}$ in plan sizes and $6 \mathrm{~cm}$ in thickness were used as testing specimens. Slabs were reinforced using wire reinforcement grid $5 \mathrm{~mm}$ in diameter with steel grade $\operatorname{Vr} 500$, which was placed near the bottom edge of slab. There was no transverse reinforcement in slab. Figure 1 shows structure of reinforced concrete slabs.

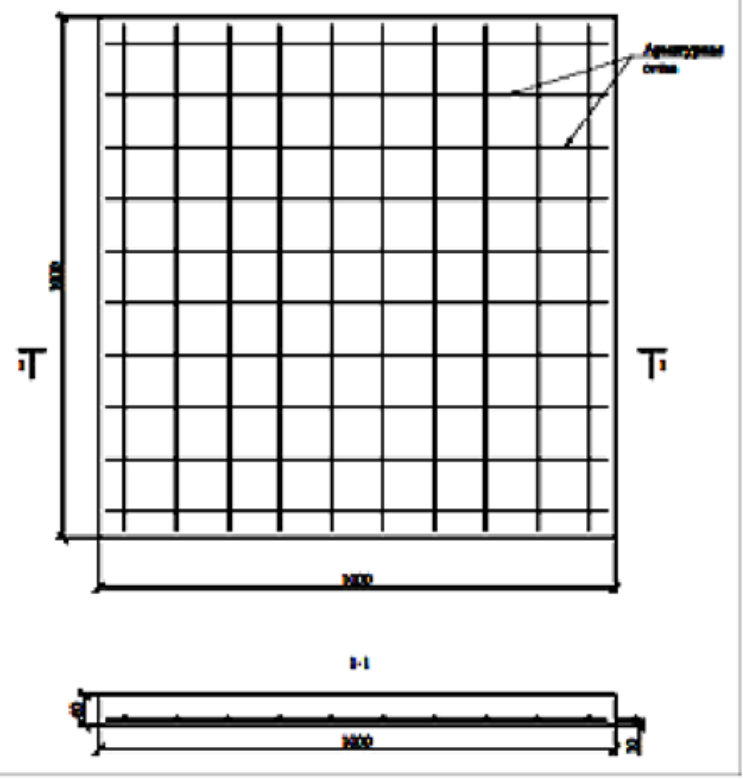

Fig. 1. Structure of reinforced concrete slabs.

Weight proportion concrete composition was $1: 1.2: 2.2$ with $\mathrm{W} / \mathrm{C}=0.32$. Composition of concrete mix included superplasticizing agent $\mathrm{C}-3$ in a quantity of $0.7 \%$ and organosilicon fluid GKZh-94 in a quantity of $0.15 \%$ of cement mass. Cement content on 1 $\mathrm{m} 3$ of concrete mix was $500 \mathrm{~kg}$. Granite ballast stone of $5-10 \mathrm{~mm}$ fraction, river sand, Portland cement of grade 400 were used for preparation of concrete mix.

Concrete casting for test specimens was done in wooden collapsible form. Compaction of the concrete mix was done on vibration table. After 3 days of curing collapsible forms were removed. Specimens were kept in humid sawdust for 28 days. After that specimens were stored at temperature of $+15 \pm 5^{\circ} \mathrm{C}$ at relative humidity of $60-65 \%$ in conditions of production space.

Concrete cubes $10 \times 10 \times 10 \mathrm{~cm}$ in sizes and prisms 10x10x40 cm in sizes were made for determination of strength and strain properties of concrete simultaneously with reinforced concrete specimens using the same concrete mix. Prism concrete strength, tension strength and elasticity modulus were determined according to [11].

Testing method for slab punching was as follows. Slabs were laid on supports in the form of metal frame situated in the center of load application area. Testing slab specimens were loaded using jack $(\mathrm{Q}=25 \mathrm{t})$. Load on slab was transferred through reinforced concrete stamps. Distance from stamp edges to internal contour of supports was set equal to $10 \mathrm{~cm}$ at each side. Thus bending of slabs was excluded. Figure 2 shows the scheme of force rig for testing slabs for punching. 


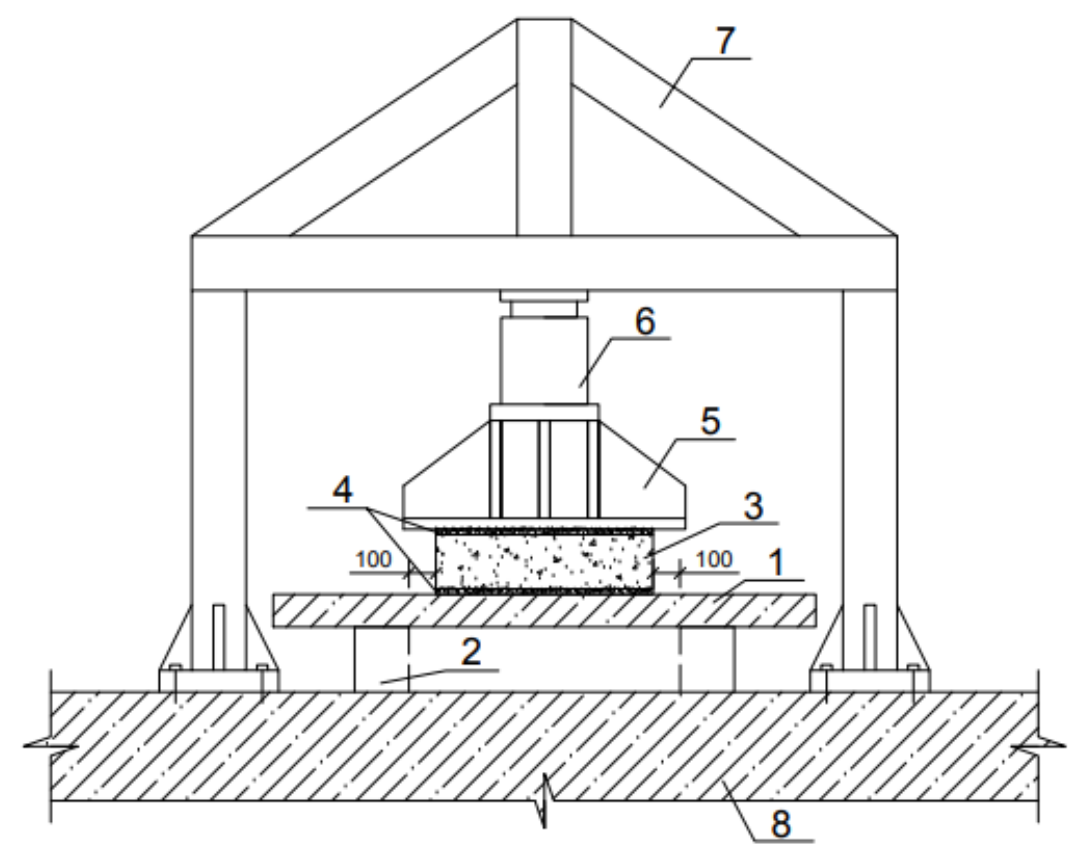

1 - tested slab specimen; 2 - metal support base; 3 -

stamp; 4 - leveling layer - cement; 5 - loading equipment;

6 - hydraulic jack; 7 - load frame; 8 - power floor.

Fig. 2. Force rig

Table 1 shows stamps marking and their sizes.

Table 1. Stamps marking and their sizes

\begin{tabular}{|l|l|l|l|l|l|}
\hline Stamp marking & St.1 & St.2 & St.3,2 & St.4 & St.5 \\
\hline Stamp size, cm & $10 \times 10$ & $10 \times 20$ & $10 \times 32$ & $10 \times 40$ & $10 \times 50$ \\
\hline Ratio of stamp sides & 1,0 & 2,0 & 3,2 & 4,0 & 5,0 \\
\hline
\end{tabular}

During tests we recorded concrete strain using strain gauges and load at which the punching of slab occurred.

\section{Test results and discussion}

Prism strength $\left(R_{b}\right)$ and initial elasticity modulus for concrete $\left(E_{b}\right)$ were acquired after concrete prisms tests for axial compression. Concrete tension strength $\left(\mathrm{R}_{\mathrm{bt}}\right)$ was determined after concrete prism tests for bending. Reinforcement bar strength $\left(R_{s}\right)$ and elasticity modulus $\left(E_{s}\right)$ were defined after bar tests for tension. Table 2 shows average values of strength and strain properties of concrete and reinforcement bars. 
Table 2. Strain and strength properties of concrete and reinforcement bars

\begin{tabular}{|c|c|c|c|c|}
\hline $\mathrm{R}_{\mathrm{b}}, \mathrm{MPa}$ & $\mathrm{E}_{\mathrm{b}} \cdot 10^{3}, \mathrm{MPa}$ & $\mathrm{R}_{\mathrm{bt}}, \mathrm{MPa}$ & $\mathrm{E}_{\mathrm{s}} \cdot 10^{5}, \mathrm{MPa}$ & $\mathrm{R}_{\mathrm{s}}, \mathrm{MPa}$ \\
\hline 52 & 39 & 2,93 & 2,17 & 415 \\
\hline
\end{tabular}

Ultimate loads $\left(\mathrm{F}_{\text {exp }}\right)$ at which slab punching occurred were acquired as a result of slab tests. Shear stress in cross-sections located at a distance of $0,5 \mathrm{~h}_{0}$ from edges of loading area was calculated using PK LIRA based on acquired test data. Shear stress curve completeness factors at fracture moment $(\omega)$ were calculated using shear stress curves across design contour. Table 3 shows test and calculation results.

Table 3. Test results for punching of slabs.

\begin{tabular}{|l|c|c|c|c|c|}
\hline Stamp marking & St.1 & St.2 & St.3,2 & St.4 & St.5 \\
\hline Stamp size, cm & $10 \times 10$ & $10 \times 20$ & $10 \times 32$ & $10 \times 40$ & $10 \times 50$ \\
\hline $\mathrm{F}_{\text {exp }}, \mathrm{kN}$ & 97,7 & 96,1 & 102,1 & 114,3 & 123,1 \\
\hline$\omega$ & 1,05 & 0,87 & 0,75 & 0,69 & 0,63 \\
\hline
\end{tabular}

Empirical dependency for shear stress curve completeness factor for slabs punching by rectangular cross-section columns was gained as a result of experimental data approximation:

$$
\bar{\omega}=0,2589 \operatorname{Ln}\left(\frac{\mathrm{b}}{\mathrm{h}}\right)+1,0,
$$

where $\mathrm{b}, \mathrm{h}$ - width and length of column cross-section respectively.

Upper and lower bounds of confidence limit for shown experimental data equal respectively:

$$
\begin{aligned}
& \omega_{\min }=0,2589 \operatorname{Ln}\left(\frac{\mathrm{b}}{\mathrm{h}}\right)+0,85 . \\
& \omega_{\max }=0,2589 \operatorname{Ln}\left(\frac{\mathrm{b}}{\mathrm{h}}\right)+1,15
\end{aligned}
$$

Figure 3 shows experimental and design results using formula (1).

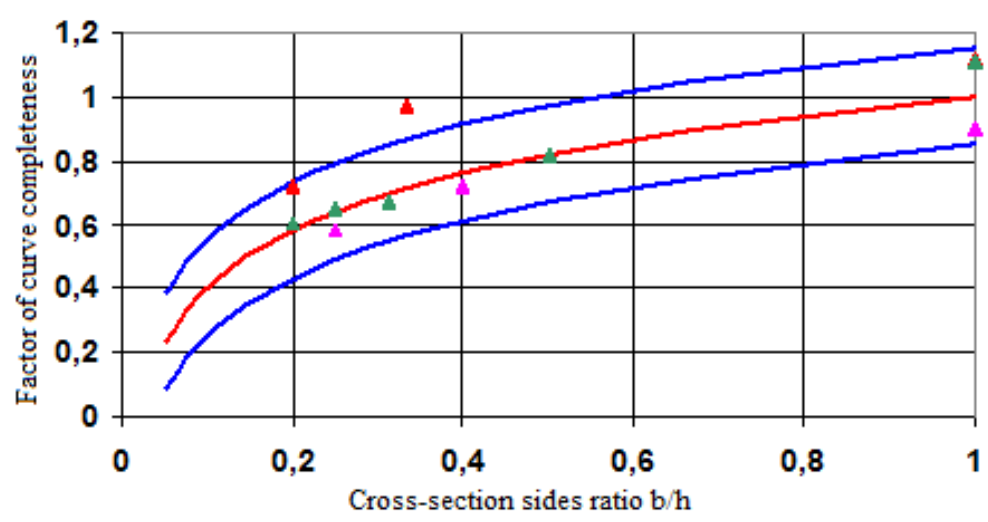

4. Tests of Filatov V.B. [5]

$\triangle$ Tests of author

using formulae (2), (3);
* Tests of Susanto T. [6]

Using formula (5);

Fig. 3. Factor of shear stress curve completeness 
Figure 3 shows that practically all test data lies in range of confidence limit for shown data. Data variation can be caused by influence of scale factor (ratio of column cross-section short side to slab thickness). This ratio for tests of Filatov V.B. [5] equaled $\mathrm{b} / \mathrm{h}_{1}=20 / 14=1,43$, for author's tests $-b / h_{1}=10 / 6=1,67$. Hence influence of scale factor $\mathrm{b} / \mathrm{h}_{1}$ was considered and the following dependency was acquired:

$$
\omega_{1}=\left(0,3885 \cdot \frac{\mathrm{b}}{\mathrm{h}_{1}}-0,3289\right) \cdot \operatorname{Ln}\left(\frac{\mathrm{b}}{\mathrm{h}}\right)+\left(0,727 \cdot \frac{\mathrm{b}}{\mathrm{h}_{1}}-0,1325\right),
$$

$\mathrm{b}, \mathrm{h}$ - width and length of column (stamp) cross-section respectively;

$\mathrm{h}_{1}$ - slab thickness.

It should be noted that formula (4) is true subject to: $1,43 \leq \mathrm{b} / \mathrm{h}_{1} \leq 1,67$ (2.6)

Value of respective bound is used in design for values of $b / h_{1}$ outside the range of specified interval.

Figure 4 shows values of shear stress curve completeness factor calculated using formula (4) for respective test values of column cross-section short side to slab thickness ratio $\mathrm{b} / \mathrm{h}_{1}$.

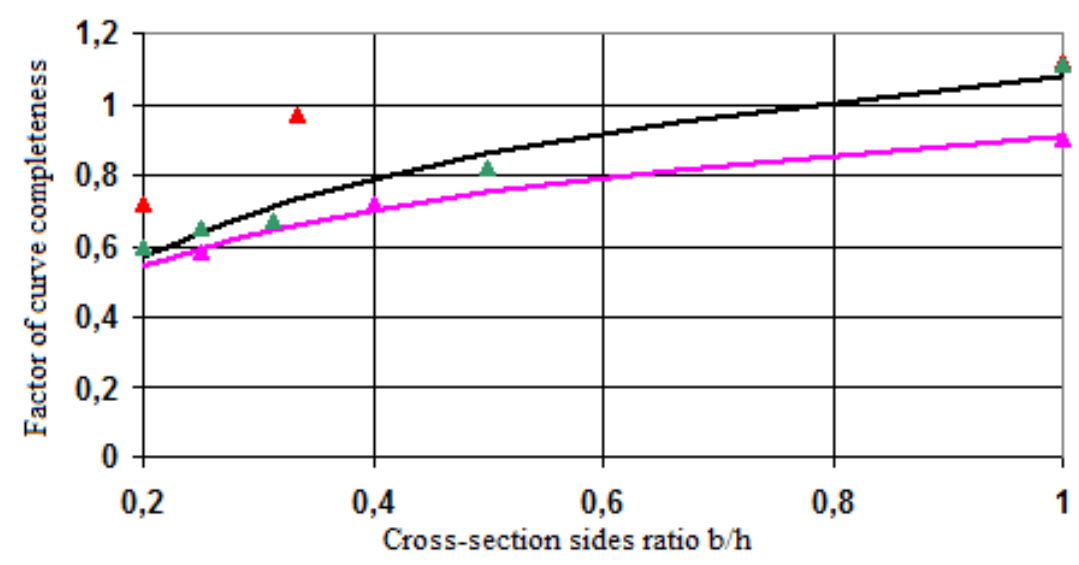

\footnotetext{
— Using formula (4) with $\mathrm{b} / \mathrm{h} 1=1.43$ Using formula (5) with $\mathrm{b} / \mathrm{h} 1=1.67$;

- Tests of Filatov V.B. [5] Tests of Susanto T. [6]

i. Tests of author
}

Fig. 4. Influence of on factor of shear stress curve completeness factor

Ultimate load born by slab concrete for rectangular cross-section columns punching is recommended to calculate using formula:

$$
\mathrm{F}_{\mathrm{ult}}=\bar{\omega} \cdot \mathrm{R}_{\mathrm{bt}} \cdot \mathrm{A}_{\mathrm{b}}
$$

where $\bar{\omega}$ - shear stress curve completeness factor calculated using formula (1). Dependency for lower bound of confidence limit should be used for engineering calculations (formula (3)).

$\mathrm{R}_{\mathrm{bt}}$ - design concrete strength for axial tension for ultimate limit state;

$\mathrm{A}_{\mathrm{b}}=\mathrm{u} \cdot \mathrm{h}_{0}$ - design area of cross-section at a distance of $0,5 \mathrm{~h}_{0}$ from edges of loading area; 
$\mathrm{u}=2 \cdot\left(\mathrm{b}+\mathrm{h}+2 \mathrm{~h}_{0}\right)-$ design cross-section contour perimeter;

$\mathrm{b}, \mathrm{h}$ - sides dimension of columns cross-section;

$\mathrm{h}_{0}$ - reduced design height of cross-section.

Table 4 shows experimental and calculated by SP 63.13330.2018 (without consideration of factor $\bar{\omega}$ ) punching strength values for slabs.

Table 4. Experimental and design values of punching strength for slabs

\begin{tabular}{|c|c|c|c|c|c|c|c|c|c|}
\hline \multirow[b]{2}{*}{$\mathrm{b} / \mathrm{h}$} & \multicolumn{3}{|c|}{ Author's tests } & \multicolumn{3}{|c|}{ Tests [5] } & \multicolumn{3}{|c|}{ Tests [6] } \\
\hline & $\begin{array}{c}\mathrm{F}_{\text {cal }}, \\
\kappa \mathrm{H}\end{array}$ & $\begin{array}{c}\mathrm{F}_{\exp }, \\
\kappa \mathrm{H}\end{array}$ & $\frac{\mathrm{F}_{\text {cal }}}{\mathrm{F}_{\text {exp }}}$ & $\begin{array}{c}\mathrm{F}_{\text {cal }}, \\
\kappa \mathrm{H}\end{array}$ & $\begin{array}{c}\mathrm{F}_{\text {exp }}, \\
\text { кН }\end{array}$ & $\frac{F_{\text {cal }}}{F_{\text {exp }}}$ & $\begin{array}{c}\mathrm{F}_{\mathrm{cal}}, \\
\kappa \mathrm{H}\end{array}$ & $\begin{array}{c}\mathrm{F}_{\mathrm{exp}} \\
\kappa \mathrm{H}\end{array}$ & $\frac{F_{\text {cal }}}{F_{\text {exp }}}$ \\
\hline 1,0 & 88 & 97,7 & 0,90 & 255 & 272 & 0,94 & 415 & 423 & 0,98 \\
\hline 2,0 & 117 & 96,1 & 1,22 & - & - & - & - & - & - \\
\hline 2,5 & - & - & - & 304 & 281 & 1,08 & - & - & - \\
\hline 3,0 & - & - & - & - & - & - & 645 & 568 & 1,14 \\
\hline 3,2 & 152 & 102,1 & 1,49 & - & - & - & - & - & - \\
\hline 4,0 & 176 & 114,3 & 1,54 & 429 & 328 & 1,31 & - & - & - \\
\hline 5,0 & 205 & 123,1 & 1,67 & - & - & - & 988 & 649 & 1,52 \\
\hline
\end{tabular}

Results presented in table 4 show that design of cast-in-place floor slabs according to recommendations of SP 63.13330 .2018 for punching by rectangular cross-section columns leads to overstatement of load bearing capacity by up to $67 \%$ in relation to experimental data

Table 5 shows experimental and calculated with formula (5) punching strength values for slabs.

Table 5. Experimental and design values of punching strength for slabs

\begin{tabular}{|c|c|c|c|c|c|c|c|c|c|}
\hline \multirow[b]{2}{*}{$\mathrm{b} / \mathrm{h}$} & \multicolumn{3}{|c|}{ Author's tests } & \multicolumn{3}{|c|}{ Tests [5] } & \multicolumn{3}{|c|}{ Tests [6] } \\
\hline & $\begin{array}{c}\mathrm{F}_{\mathrm{cal}}, \\
\mathrm{kN}\end{array}$ & $\begin{array}{c}\mathrm{F}_{\exp }, \\
\mathrm{kN}\end{array}$ & $\frac{\mathrm{F}_{\text {cal }}}{\mathrm{F}_{\text {exp }}}$ & $\begin{array}{c}\mathrm{F}_{\mathrm{cal}}, \\
\mathrm{kN}\end{array}$ & $\begin{array}{c}\mathrm{F}_{\text {exp }}, \\
\mathrm{kN}\end{array}$ & $\frac{F_{\text {cal }}}{F_{\text {exp }}}$ & $\begin{array}{c}\mathrm{F}_{\mathrm{cal}}, \\
\mathrm{kN}\end{array}$ & $\begin{array}{c}\mathrm{F}_{\exp } \\
\text { кH }\end{array}$ & $\frac{F_{\text {cal }}}{F_{\text {exp }}}$ \\
\hline 1,0 & 88 & 97,7 & 0,90 & 255 & 272 & 0,94 & 415 & 423 & 0,98 \\
\hline 2,0 & 96 & 96,1 & 1,00 & - & - & - & - & - & - \\
\hline 2,5 & - & - & - & 232 & 281 & 0,82 & - & - & - \\
\hline 3,0 & - & - & - & - & - & - & 461 & 568 & 0,81 \\
\hline 3,2 & 106 & 102,1 & 1,04 & - & - & - & - & - & - \\
\hline 4,0 & 113 & 114,3 & 0,99 & 275 & 328 & 0,84 & - & - & - \\
\hline 5,0 & 120 & 123,1 & 0,97 & - & - & - & 576 & 649 & 0,89 \\
\hline
\end{tabular}

Results presented in table 5 show that consideration of shear stress curve completeness factor in calculation of ultimate strength for slabs punching by rectangular cross-section columns leads to values of ultimate loads close to experimental data. Understatement of load bearing capacity in relation to experimental data equals $9 \%$ in average.

\section{Conclusions}

Conveyed research showed that design of cast-in-place floor slabs in the absence of bending moments according to recommendations of SP 63.13330 .2018 for punching by 
rectangular cross-section columns leads to overstatement of load bearing capacity by up to $67 \%$ in relation to experimental data.

Non-uniformity in stress and strain distribution across rectangular cross-section column perimeter can be taken into account using shear stress curve completeness factor.

Suggested dependencies for shear stress curve completeness factor allow to decrease divergence between design and experimental values of slab strength for rectangular crosssection columns punching (in average understatement of load bearing capacity was $9 \%$ in relation to experimental data).

Article shows research results for one slab thickness. Further research is expected to investigate influence of scale factor (ratio of column cross-section short side to slab thickness) on slab punching strength.

\section{References}

1. Ivanov A D Zalesov A S Raschet prochnosti ploskih plit perekrytij bez poperechnoj armatury monolitnyh karkasnyh zdanij na prodavlivanie Izvestiya vuzov Stroitelstvo i arhitektura 2003 S 200205

2. Tamrazyan A G Zvonov $\mathrm{Yu} \mathrm{N}$ K otsenke nadezhnosti zhelezobetonnyh ploskih bezbalochnyh plit perekrytij na prodavlivanie pri dejstvii sosredotochennoj sily $\mathrm{V}$ usloviyah vysokih temperatur Promyshlennoe i grazhdanskoe stroitelstvo 20167 S 24 28

3. Silantev A S Plotnikov A I Problemy ucheta dejstvitelnoj raboty uzlov sopryazheniya ploskih bezbalochnyh plit zhelezobetonnyh perekrytij s kolonnami Vestnik MGSU 20091 S 7173

4. Juan Sagaseta Aurelio Muttoni Miguel Ferna'ndez Ruiz Luca Tassinari Non axis symmetrical punching shear around internal columns of RC slabs without transverse reinforcement Magazine of Concrete Research 2011636 P 441457

5. Shekhovtsov I V Prochnost i deformativnost zhelezobetonnyh plit bez poperechnoj armatury pri prodavlivanii dis kand tekh nauk 052301 Odessa $199218 \mathrm{~s}$

6. Bolgov A N Rabota uzlov sopryazheniya kolonn iz vysokoprochnogo betona s perekrytiem v monolitnyh zdaniyah s ramno svyazevoj sistemoj diss kand tekhn nauk Moskva $2005151 \mathrm{~s}$

7. Zalesov A S Dorofeev V S SHekhovtsov I V Prochnost i deformativnost plit na prodavlivanie Beton i zhelezobeton 81992 S 1417

8. Filatov V B Silovoe soprotivlenie zhelezobetonnyh monolitnyh ploskih plit perekrytij pri prodavlivanii kolonnami pryamougolnogo secheniya V B Filatov Izvestiya Samarskogo nauchnogo tsentra RAN 2012 T 1445 S 13221324

9. Susanto $\mathrm{T}$ Punching Shear Strength of Slabs with Openings and Supported on Rectangular Columns T Susanto H K Cheong K L Kuang J Z Geng ACI Structural Journal 2004 V 1015 P 678687

10. Filatov V B Bubnov E P Ehksperimentalnye issledovaniya prochnosti ploskih zhelezobetonnyh plit pri prodavlivanii Promyshlennoe i Grazhdanskoe Stroitelstvo 20172 S 8691

11. Karpenko N I Prakticheskaya metodika rascheta zhelezobetonnyh plit na prodavlivanie po razlichnym skhemam N I Karpenko S N Karpenko Beton i zhelezobeton 20125 S 1016

12. Bochkarev M A Vliyanie geometricheskoj formy secheniya kolonny na napryazhenno deformirovannoe sostoyanie zhelezobetonnoj plity pri prodavlivanii Pokolenie 
Budushchego Vzglyad Molodyh Uchenyh 2019 Kursk Zakrytoe aktsionernoe obshchestvo Universitetskaya kniga 2019 S 113117

13. Ermuhanov K E Obobshchennyj analiz rascheta prochnosti plit na prodavlivanie po otechestvennym i zarubezhnym normam Beton i Zhelezobeton 1992 4 S 1113

14. Filatov V B Galyautdinov Z Sh Analiz napryazhenno deformirovannogo sostoyaniya plity pri prodavlivanii na konechno ehlementnyh modelyah Novoe v Arhitekture Proektirovanii Stroitelnyh Konstruktsij i Rekonstruktsii Cheboksary Chuvashskij gosudarstvennyj universitet imeni I N Ulyanova 2018 S 214222

15. Bolgov A N Rabota uzlov sopryazheniya kolonn iz vysokoprochnogo betona $\mathrm{s}$ perekrytiem v monolitnyh zdaniyah s ramno svyazevoj sistemoj diss kand tekhn nauk Moskva $2005151 \mathrm{~s}$

16. Filatov V B Galyautdinov Z Sh Analiz napryazhenno deformirovannogo sostoyaniya plity pri prodavlivanii na konechno ehlementnyh modelyah Novoe V Arhitekture Proektirovanii Stroitelnyh Konstruktsij I Rekonstruktsii Cheboksary Chuvashskij gosudarstvennyj universitet imeni I N Ulyanova 2018 S 214222. 